\title{
Hubungan Keaktifan Dan Motivasi Terhadap Pembelajaran Online Pada Mahasiswa
}

\author{
Wahyudha Tri Setiyoaji, Maria Claudia Sodakain, Rais Muktamar Amin, Endang \\ Purwaningsih, Parno* \\ Program Studi Pendidikan Fisika, Universitas Negeri Malang \\ *Email: parno.fmipa@um.ac.id
}

Received: 14 Januari 2021;

Accepted: 3 Agustus 2021;

Published: 21 Oktober 2021

DOI: http://dx.doi.org/10.29303/jpft.v7i2.2396

\begin{abstract}
Government policy on online learning as an effort to prevent the transmission of the spread of COVID-19 in schools, especially in classrooms. Therefore, this policy creates social restrictions and the exclusion of face-to-face learning systems and will temporarily be replaced by online learning through several digital platforms that have been selected by the teacher and each school. The purpose of this study was to determine the relationship between Activeness and Motivation on Online Learning in Students. This research uses quantitative and qualitative approaches, researchers distribute questionnaires in the form of google form. Based on the results of research on the relationship of online learning to student learning activeness and motivation in the activeness category, $64 \%$ who answered YES and $36 \%$ answered no respectively. In the category of motivation, it shows that $78.5 \%$ answered YES and $21.5 \%$ answered NO. Based on these results, it can be seen that activeness and motivation can influence students in online learning.
\end{abstract}

Keywords: Online Learning; Activeness; Motivation

\section{PENDAHULUAN}

Sejak awal maret 2020 hingga kini indonesia masih menghadapi pandemi covid-19. Beberapa kebijakan diterapkan untuk mengurangi individu terjangkit virus. Pemerintah mengeluarkan surat edaran nomor 4 tahun 2020 tentang pelaksanaan kebijakan pendidikan dalam masa darurat penyebaran covid, berdasarkan surat edaran tersebut proses pembelajaran yang awalnya dilakukan secara langsung atau tatap muka harus dilaksanakan secara online jarak jauh.

$$
\text { Pembelajaran online dianggap }
$$

menjadi solusi dari semakin meningkatnya penyebaran virus covid (Tabacova, 2020; Setiaji, 2020). Menurut (Tabakova, 2020) menyebarnya virus ini menyebabkan gangguan pada kehidupan sehari-hari, banyak negara telah meminta pihak sekolah untuk menutup kegiatan pembelajaran secara tatap muka, hal tersebut menyebabkan banyak anak remaja putus sekolah. Untuk mengantisipasi hal tersebut, pembelajaran online dapat digunakan agar pembelajaran tetap berjalan sebagaimana mestinya.

Perguruan tinggi telah menggunakan pembelajaran daring untuk memudahkan dalam proses pembelajaran, beberapa penelitian (Crews \& Parker, 2017; Mather \& Sarkans, 2018) menjelaskan beberapa manfaat ketika menerapkan pembelajaran daring, seperti setiap individu dapat mengakses pembelajaran dengan mudah sehingga dapat menghilangkan hambatan dalam mengikuti pembelajaran (Riaz, 2018), pembelajaran dianggap efektif saat diterapkan dalam perguruan tinggi, akan tetapi tidak semua pembelajaran dapat dilakukan secara online (Pilkington, 2018).

Pembelajaran yang dilakukan secara online tentu memiliki perbedaan dengan pembelajaran yang dilakukan secara tatap muka, pendidik diharuskan memiliki metode pembelajaran yang sesuai, kreatif, dan inovatif, sehingga akan menciptakan proses pembelajaran yang kondusif meskipun dilaksanakan dalam ruang lingkup yang 
terbatas secara virtual. Motivasi belajar memiliki pengaruh yang cukup besar dalam pembelajaran. Menurut Purwasih \& Putri (2020) apabila mahasiswa memiliki motivasi belajar yang rendah akan berdampak pada menurunnya keaktifan mahasiswa di dalam kelas sehingga prestasi belajar mahasiswa juga turut terdampak. Penelitian yang dilakukan oleh Purwaningsih (2018) menyampaikan bahwa keaktifan dan motivasi belajar mahasiswa akan memiliki pengaruh terhadap prestasi belajar.

Motivasi merupakan suatu konstruksi teori yang digunakan untuk menjelaskan keinginan, perilaku yang ditunjukkan untuk mencapai suatu tujuan (Brophy dalam Fitriyani et al., 2020). Motivasi yang ada pada diri seseorang akan memunculkan semangat untuk mengikuti pembelajaran. Motivasi dapat mendorong individu untuk bertindak kearah yang diharapkan, sehingga aktivitas akan menjadi bagian penting dalam suatu motivasi (Lee \& Martin, 2017). Motivasi belajar akan membuat individu menjadi tertarik untuk belajar terus menerus.

Motivasi merupakan suatu pedoman yang menjadi dasar kegiatan belajar agar tercapai suatu tujuan yang jelas (Kiswoyowati, 2011), terdapat beberapa ciri individu dengan motivasi tinggi, seperti rajin dalam mengerjakan tugas, memiliki semangat yang besar, berani menghadapi setiap kesulita, tidak bergantung kepada orang lain, mampu mempertahankan argumentasi dan mampu memecahkan masalah. Selama kegiatan pembelajaran, mahasiswa diharuskan untuk berpartisipasi secara aktif, hal tersebut terlihat dari bagaimana mahasiswa memusatkan perhatian pada materi yang disampaikan oleh dosen, serta bertanya apabila tidak memahami materi yang disampaikan, dan apabila diberikan tugas mahasiswa akan mengerjakan tugas tersebut dengan tekun.
Pada hakikatnya, proses pembelajaran merupakan interaksi antara mahasiswa dengan dosen. Menurut Mulyasa (2002) pembelajaran berhasil apabila setidaknya sebagian peserta yang terlibat dalam pembelajaran terlibat secara aktif, baik secara fisik, mental, maupun sosial. Oemar (2002) menyampaikan bahwa tugas pendidik ialah mengajar, sedangkan tugas utama mahasiswa ialah belajar. Menurut Sardiman (2001) belajar mengacu pada aktifitas yang dilakukan oleh mahasiswa dan mengajar mengacu pada aktifitas yang dilakukan oleh mahasiswa. Mengajar ialah suatu usaha yang dilakukan untuk menciptakan suasana yang mendukung berlangsungnya proses pembelajaran.

Penelitian ini dilakukan untuk mengetahui keaktifan serta motivas belajar pada mahasiswa dalam pembelajaran online di masa pandemi covid-19.

\section{METODE PENELITIAN}

Penelitian ini dilakukan secara online di Malang Surabaya, Tulungagung, dengan sasaran lokasi penelitian adalah mahasiswa di beberapa Universitas di kota tersebut. Menggunakan pendekatan kuantitatif dan kualitatif, peneliti menyebarkan angket berupa google form. Peneliti mencoba memperoleh gambaran tentang keaktifan dan motivasi dalam pembelajaran online mahasiswa di beberapa Universitas di Malang Surabaya, Tulungagung.

Dalam desain penelitian yang menggunakan penelitian korelasional memiliki dua variabel yaitu variabel bebas dan variabel terikat. Variabel bebas (X) pada penelitian ini adalah keaktifan belajar mahasiswa, sedangkan variabel terikat $(\mathrm{Y})$ adalah motivasi belajar mahasiswa. Koefisien korelasi yang dihasilkan mengindikasikan tingkatan atau derajat hubungan antara motivasi belajar dan keaktifan belajar mahasiswa. Analisis 
korelasi digunakan untuk mengetahui hubungan antara variabel $\mathrm{X}$ (keaktifan belajar mahasiswa) dengan varibel $\mathrm{Y}$ (motivasi belajar mahasiswa). Analisis korelasi dihitung menggunakan rumus koefisien korelasi Pearson dengan SPSS V22.

\section{HASIL DAN PEMBAHASAN}

Berdasarkan hasil penelitian yang diperoleh bahwa kategori keaktifan mendapatkan skor terendah dengan skor 4, skor tertinggi 16 dan rentangan data 12 . Kategori motivasi mendapatkan skor terendah dengan skor 8, skor tertinggi 16 dan rentangan data 8 . Dari hasil pengolahan data diperoleh bahwa kategori keaktifan skor rata-rata 10,26; median 10; standar deviasi sebesar 6,074; dan standar error nya 0,34854 . Sedangkan hasil pengolahan data pada kategori motivasi memperoleh skor rata-rata 12,56 ; median 13 ; standar deviasi sebesar 1,82; dan standar error nya 0,25740.

Berdasarkan hasil penelitian hubungan pembelajaran online terhadap keaktifan dan motivasi belajar mahasiswa pada kategori keaktifan menujukan masing-masing 64\% yang menjawab YA dan $36 \%$ yang menjawab tidak. Pada kategori motivasi menunjukan masing-masing $78.5 \%$ yang menjawab YA dan $21.5 \%$ yang menjawab TIDAK. Berdasarkan hasil tersebut dapat dilihat bahwa keaktifan dan motivasi dapat mempengaruhi mahasiswa dalam belajar online, hal tersebut menujukkan bahwa mahasiswa berusaha untuk mengikuti pembelajaran dengan baik.

Pada pembelajaran online mahasiswa aktif dalam mendengarkan dosen saat memberikan materi, mahasiswa juga berpartisipasi aktif dalam proses pembelajaran dengan menjawab beberapa pertanyaan yang diberikan oleh dosen. Hal tersebut sejalan dengan pernyataan Mulyasa (2002) bahwa apabila mahasiswa menunjukkan keaktifannya selama pembelajaran, maka pembelajaran dapat dikatakan berhasil. Pada saat berdiskusi, mahasiswa juga aktif dalam memberikan pendapat sesuai topik pembelajaran. Mahasiswa juga tetap aktif dalam melakukan presentasi dan melakukan diskusi dengan baik dan lancar, dapat dikatakan bahwa mahasiswa memiliki motivasi yang cukup tinggi, ketika menemukan permasalahan yang sulit mahasiswa tidak ragu untuk mengajukan pertanyaan pada dosen. Meskipun pembelajaran dilakukan secara online, mahasiswa tetap memotivasi dirinya untuk tetap belajar guna mendapatkan nilai yang bagus. Melalui kuisioner yang telah dibagikan kepada mahasiswa, mahasiswa memotivasi diri mereka untuk tetap mengikuti kuliah dengan semangat meskipun kuliah secara online. Motivasi belajar mahasiswa juga sangat baik dalam mempersiapkan ujian, mahasiswa selalu mengulangi materi yang telah diajarkan dosen dengan cara membuat ringkasan untuk sebagai bahan belajar mereka.

Analisis korelasi antara variabel keaktifan dan variabel motivasi terhadap pembelajaran online adalah berdasarkan nilai signifikasi diketahui nilai Sig. Antara keaktifan (Y) dan motivasi (X) terhadap pembelajaran online terdapat korelasi, yang dapat dilihat dari nilai signifikasinya. Dari hasil yang di dapatkan keaktifan dan motivasi memiliki nilai signifikasi sebesar 0,025, jika nilai Sig $<0,05$ maka terdapat korelasi atau hubungan antara kedua variabel.

Pembelajaran yang diberikan dosen dibuat semenarik mungkin sehingga mahasiswa aktif dalam proses pembelajaran. Dosen dalam melakukan pembelajaran online menggunakan model serta media yang mendukung proses pembelajaran. Hal ini dapat membuat mahasiswa aktif dalam 
mengikuti proses pembelajaran. Dengan adanya keaktifan mahasiswa, motivasi belajar dapat meningkat. Jika mahasiswa tidak aktif di kelas, maka motivasi belajar mahasiswa juga kurang. Dapat disimpulkan bahwa keaktifan dan motivasi terhadap pembelajaran online memiliki nilai korelasi atau hubungan. Hasil tersebut juga ditunjukkan pada penelitian yang dilakukan oleh Marzuqoh et al., (2020) mengenai hubungan antara motivasi, keaktifan, gaya belajar dengan prestasi belajar matematika siswa SMA se-Kecamatan Banguntapan, menunjukkan hasil bahwa terdapat hubungan positif serta signifikan antara motivasi, keaktifan dan gaya belajar dengan prestasi belajar matematika dengan nilai koefisien determinasi sebesar 0,471.

Pada penelitian yang dilakukan oleh Harleni \& Asniar (2021) juga menunjukkan hasil bahwa terdapat hubungan antara keaktifan belajar dan motivasi belajar pada pembelajaran dengan nilai koefisien korelasi sebesar 0,975 pada taraf "sangat kuat", pada data tersebut disajikan hasil korelasi yang positif menunjukkan apabila keaktifan belajar siswa tinggi, maka motivasi siswa juga tinggi, sebaliknya apabila siswa memiliki motivasi belajar yang rendah, maka motivasi belajar siswa juga rendah. Siswa yang motivasi belajarnya tinggi akan aktif dalam mengikuti proses pembelajaran, sehingga proses belajar akan berjalan dengan maksimal (Harleni \& Asniar, 2021). Menurut Ansori (2010) semangat atau antusiasnya siswa selama mengikuti pembelajaran serta keinginan siswa memperhatikan penjelasan materi oleh dosen dapat menunjukkan tinggi rendahnya motivasi belajar siswa.

\section{PENUTUP}

Berdasarkan hasil penelitian dan pembahasan dapat disimpulkan bahwa keaktifan dan motivasi memiliki korelasi dengan nilai signifikasi sebesar 0,025. Pembelajaran di kelas di rancang sebaik mungkin oleh dosen, sehingga mahasiswa dapat aktif dalam mengikuti pembelajaran

\section{REFERENSI}

Crews, J., \& Parker, J. (2017). The Cambodian Experience: Exploring University Students' Perspectives for Online Learning. Issues in Educational Research, 27(4), 697-719.

Fitriyani, Y., Fauzi, I., \& Sari, M. Z. (2020). Motivasi Belajar Mahasiswa Pada Pembelajaran Daring Selama Pandemik Covid-19. Jurnal Hasil Penelitian Dan Kajian Kepustakaan Di Bidang Pendidikan, Pengajaran Dan Pembelajaran, 6(2), 165-175. http://ojs.ikipmataram.ac.id/index.php/j urnalkependidikan/index\%0AJuli

Harleni, S., \& Asniar. (2021). Hubungan Keaktifan Belajar Dengan Motivasi Belajar Matematika Siswa Kelas VIII Pada Masa Pandemi Covid 19 Di SMP Negeri 2 Satu Atap Batang Serangan. Jurnal Serunai Matematika, 13(1), 74 80.

Kiswoyowati, A. (2011). Pengaruh Motivasi Belajar dan Kegiatan Belajar Mahasiswa Terhadap Kecakapan Hidup Mahasiswa. Journal Pendidikan, 1, 120-126.

Lee, J., \& Martin, L. (2017). Investigating students' perceptions of motivating factors of online class discussions. International Review of Research in Open and Distance Learning, 18(5), 148-172.

https://doi.org/10.19173/irrodl.v18i5.2 $\underline{883}$

Marzuqoh, F. A., Sujadi, A. A., \& Arigiyati, T. A. (2020). Hubungan antara motivasi, keaktifan, gaya belajar dengan prestasi belajar matematika siswa SMA se-Kecamatan Banguntapan. UNION: Jurnal Pendidikan Matematika, 8(1), 53-61. https://doi.org/10.35816/jiskh.v12i2.44 $\underline{9}$ 
Mather, M., \& Sarkans, A. (2018). Student Perceptions of Online and Face-to-Face Learning. International Journal of Curriculum and Instruction, 10(2), 6176.

Mulyasa. (2002). Manajemen Berbasis Sekolah: Konsep, Strategi dan Implementasi. Bandung: Remaja Rosda Karya

Mustofa, M. I., Chodzirin, M., Sayekti, L., \& Fauzan, R. (2019). Formulasi Model Perkuliahan Daring sebagai Upaya Menekan Disparitas Kualitas Perguruan Tinggi. Walisongo Journal of Information Technology, 1(2), 151. https://doi.org/10.21580/wjit.2019.1.2. $\underline{4067}$

Oemar, Hamalik. (2002). Psikologi Belajar Mengajar. Bandung: Sinar Baru Algessindo

Pilkington, O. A. (2018). Active Learning for an Online Composition Classroom : Blogging as an Enhancement of Online Curriculum. Journal of Educational Technology Systems, 47(2), 1-14. https://doi.org/10.1177/004723951878 8278.

Purwaningsih, S. (2018). Pengaruh Keaktifan Dan Motivasi Terhadap Hasil Belajar Mahasiswa Dalam Penerapan Model Pembelajaran Kooperatif Tipe Stad Materi Turunan Fungsi Pada Mahasiswa Kelas Xi Is 2 Sma N 15 Semarang. Jurnal Karya Pendidikan Matematika, 5(2), 63. https://doi.org/10.26714/jkpm.5.2.2018 $.63-67$

Purwasih, S. M., \& Putri, R. K. (2020). Peningkatan Keaktifan dan Motivasi belajar Mahasiswa melalui Pendekatan Kontekstual. Jurnal Statistika, 13(2), 14.

Riaz, A. (2018). Effects of Online Education on Encoding and Decoding Process of Students and Teachers. International Conference E-Learning, 4248. https://files.eric.ed.gov/fulltext/ED590 288.pdf.
Sardiman. (2001). Interaksi dan Motivasi belajar Mengajar. Jakarta: Raja Grafindo Persada

Setiaji, B., \& Dinata, P. A. C. (2020). Analisis kesiapan mahasiswa jurusan pendidikan fisika menggunakan elearning dalam situasi pandemi Covid19. Jurnal Inovasi Pendidikan IPA, 6(1), 59-70.

Tabakova, V. (2020). E-learning - from first experiences in medical physics and engineering to its role in times of crisis. Health and Technology, 10(6), 13851390 https://doi.org/10.1007/s12553020-00474-x 